All Papers

Osgoode Hall Law School of York University Osgoode Digital Commons

Research Papers, Working Papers, Conference Papers

2008

\title{
Writing Resistance into International Law
}

Ruth Buchanan

Osgoode Hall Law School of York University, rbuchanan@osgoode.yorku.ca

Follow this and additional works at: http://digitalcommons.osgoode.yorku.ca/all_papers

Part of the Law Commons

\section{Repository Citation}

Buchanan, Ruth, "Writing Resistance into International Law" (2008). All Papers. 11.

http://digitalcommons.osgoode.yorku.ca/all_papers/11

This Article is brought to you for free and open access by the Research Papers, Working Papers, Conference Papers at Osgoode Digital Commons. It has been accepted for inclusion in All Papers by an authorized administrator of Osgoode Digital Commons. 


\title{
Writing Resistance into I nternational Law
}

\author{
Ruth Buchanan*
}

\section{Introduction}

Can resistance be written into international law without at the same time being written out of it? For international lawyers, it seems as if the answer is usually a resounding chorus of 'yes!' However, for many other observers, especially those located in the global South, the matter is much less clear, and international law is seen as implicated in the preservation and maintenance of a deeply unjust global order. This essay considers how these debates might play themselves out within the work of third world-allied international legal scholars, whose professional and political commitments may not be as smoothly aligned as is apparently the case for those in the international law mainstream. That is, for most of its practitioners, international law is a decidedly modernist enterprise; a collective undertaking that is "animated by a progressive and universalistic spirit (and) firm confidence in the ability of liberal political institutions to transform the world into a democratic and rule-governed Kantian Volkerstaat." ${ }^{1}$ According to Orford, there is a 'generous and liberal impulse within the mainstream (of international law) that wants the voice of the other to be heard, and which believes, in true cosmopolitan fashion, that we have now arrived at the moment when the truth of our history will finally be available to us. ${ }^{2}$ In mainstream debates, the twentieth century trajectories of decolonization and human rights are often cited as strong evidence for the claim that the political project of international law has the capacity to, and does, respond to acts of resistance and the demands for inclusion from the politically excluded that they represent. Yet, these very same liberal commitments also lead international lawyers to adhere to ideas and practices that function to reproduce the very hierarchies and exclusions that they ostensibly stand against. For some critics, this means that the cooptation and continued marginalization of resistant movements by international law are predictable, almost inevitable.

In pressing the question further, I've suggested that we must turn to the margins of international legal scholarship, and particularly to the work of critical and third world international law scholars who have by now amassed a daunting array of (mostly historical) evidence that seeks to dis-enchant international law by revealing its imperialist, gendered and racist underpinnings. This is the work that identifies itself under the rubric of 'Third World Approaches to International Law" or 'TWAIL'. ${ }^{3}$ One can find in this body of literature repeated calls for the

\footnotetext{
* Associate Professsor, Osgoode Hall Law School. This paper was originally prepared for a workshop called "Situating TWAIL: Inspirations, Challenges, Possibilities" at the University of British Columbia in May, 2008. The author would like to thank the Organizing Committee for that event for the invitation and the participants of the workshop for a stimulating and enlightening conversation. All inaccuracies, errors and omissions in the following are entirely my own.

${ }^{1}$ Martti Koskeniemmi, (2007) 'What Should International Lawyers Learn from Karl Marx?' in International Law and its Others, Anne Orford, ed. (Cambridge U. Press: 2006)

${ }^{2}$ Orford, “A Jurisprudence of the Limit,' International Law and its Others, p.3.

3 'TWAIL' references a body of scholarship is much too voluminous to be comprehensively cited, but some notable contributions would include Anthony Anghie, Imperialism, Sovereignty and the Making of International Law (Cambridge: Cambridge U. Press 2004); Balakrishnan Rajagopal, International Law from Below: Development, Social Movements and Third World Resistance (Cambridge: Cambridge University Press, 2003); Upendra Baxi, The Future of Human Rights (Oxford U. Press: 2002); Makau Mutua, Human Rights: A Political and Cultural Critique (2002: U of Penn. Press) B.S. Chimni (2006) "Third World Approaches to International Law: A Manifesto" 8 International Community Law Review 327; Obiora Okafor (2006) 'Poverty, Agency and Resistance in the Future of International Law: an African
} 
importance of integrating consideration for the suffering of third world peoples, the ongoing perpetuation of economic injustice by international institutions, and acts of resistance by states and social movements in the South, into an account of international law's history as well as its possible futures. Much of this work addresses important oversights in mainstream approaches by attending to and detailing the imperial foundations of modern international law and the multiple trajectories by which that imperialist history can be linked to the ongoing failures of international law to respond meaningfully to the demands for inclusion made by states and peoples of the developing world. ${ }^{4}$

Notwithstanding ongoing critiques of the myth of Westphalia, the notion that the international legal order is comprised of a community of equally sovereign nation-states persists in international legal thought. ${ }^{5}$ Despite the critique, international lawyers (and the rest of us) continue to 'write and behave as if the sovereign were all powerful' and in so doing we 'memorialize a certain set of knowledges and practices, which place the sovereign state at the foreground of the law, and a certain group of actors as principle lawmakers." ${ }^{6}$ In the TWAIL literature, however, one finds that the state, while it is not dismissed, is problematized as the sole or privileged site of third world resistance. In its place, Third World 'peoples' and social movements have been identified as an important ground of legal agency and resistance. The work goes on to document the ways in which the aspirations of those people have been betrayed by the discourses of 'development' and 'human rights;' undertakings which are explicitly intended for the benefit of third world people. ${ }^{7}$ For most of the scholars writing out of critical and/or third world approaches to international law, then, the law's liberal promise has lost much, though not all, of its luster. Yet, without faith in that promise, how to 'map the relation between critique, the other, and responsibility' is not at all clear. ${ }^{8}$

Yet admirably, for most of those whose writing is identified with TWAIL, this uncertainty does not relieve the scholar of another type of commitment: to address the explicitly political questions of agency, resistance, and the future of the international legal order. ${ }^{9}$ But in the deepening gloom brought on by expanding mechanisms of indirect economic governance by international economic institutions and the creation of an integrated global economic governance structure that constrains and supplants those of (especially poorer) states ${ }^{10}$, the spaces of resistance appear to be shrinking, and these questions are increasingly fraught. It is this narrow and dangerous terrain that I attempt to briefly assay here.

perspective” 27:5 Third World Quarterly 799-814; Anthony Anghie, Bhupinder Chimni, Karin Mickelson and Obiora Okafor, eds. The Third World and International Order: Law, Politics, and Globalization (Martinus Nijhoff Publishers: 2003). See also TWAIL-themed special issues of the Osgoode Hall Law Journal vol. 43 (2005), Third World Quarterly (2006) vol. 27:5, and International Community Law Review (2007) vol. 9:4.

4 For example, Anghie, 'Civilization and Commerce: The Concept of Governance in Historical Perspective’ (2000) 45 Villanova Law Review 887 - 911.

${ }^{5}$ See Orford, supra note 2, p. 7; also Oren Perez (forthcoming) "Purity Lost: The Paradoxical Face of the New Transnational Legal Body" Brooklyn International Law Journal; Paul Schiff Berman (2005) "From International Law to Law and Globalization” 43 Columbia Journal of Transnational Law 485.

${ }^{6}$ Orford, supra n. 2, p.12.

${ }^{7}$ Makau Mutua, supra note 3; Rajagopal Balakrishnan (2006) "Counterhegemonic International Law: Rethinking Human Rights and Development as a Third World Strategy” 27:5 Third World Quarterly.

${ }^{8}$ Orford, supra note 2.

${ }^{9}$ As Chimni puts it, "From the standpoint of TWAIL, it is necessary first, to make the story of resistance an integral part of the narration of international law." Supra note 3 at p. 22.

${ }^{10}$ Both Upendra Baxi and B.S. Chimni have made strong arguments regarding the negative implications of the integration of global economic space for poorer countries. See Chimni, supra note 3. Also Upendra Baxi, (2006) "What should the Third Word Expect from International Law" Third World Quarterly. 
In the very focused consideration of two recent contributions to the TWAIL literature that follows, I seek to draw out specifically how the authors traverse this terrain-where they map the possible spaces for resistance of third world states and peoples, how they suggest that this resistance might manifest itself, and how they conceive of the relations between resistance and international law. Does third world resistance have the potential to transform international law, moving us in the direction of a more just international order? If so, is the process of change incremental or sudden? The commitment to explicitly addressing the difficult political questions of the justice of the international order, unfortunately, does not make the answers any less elusive. Rather, I will suggest that what is highlighted in these attempts is the ambiguous, perhaps even contradictory, nature of the project in which the third world international legal scholar finds herself engaged.

\section{De-elitizing International Law through Counterhegemony}

One TWAIL scholar well-known for his efforts to theorizing resistance in relation to international law is Balakrishnan Rajagopal. ${ }^{11}$ Rajagopal has directed his efforts to, in his words, 'de-elitizing' international law by writing resistance into it, in an effort to make it 'recognize' subaltern voices. ${ }^{12}$ Without these voices, Rajagopal argues that even such potentially resistant discourses as human rights and development will become swallowed up in the expanding scope of 'hegemonic' international law. In his account, these discourses retain a counter-hegemonic potential that can be realized by drawing on the insights and praxis of third world social movements. According to Rajagopal, the 'praxis of social movements offers a fundamental epistemological challenge to the premises of liberal internationalism':

"Social movements seek to redefine the 'political' in non-institutional, non-party, cultural terms. They seek to redefine the 'economy' in place-based, rather than spacebased, terms. And they seek to redefine "law' in radically pluralistic terms." 13

This last claim is perhaps the most essential for an understanding of the political potential of the encounter between international law and social movements. In the realm of human rights, for example, we would all be familiar with the critiques of universalism and statism that evacuate rights of meaning and utility for many non-western legal subjects. The need to pluralize rights discourse is widely accepted, as would be the important role of social movements in that process. The challenge encountered by this project, then, is to think more specifically about how the practices of social movements might be understood as operating in and through legal institutions and forms.

Rajagopal takes on this challenge in a relatively recent article entitled "Counter-hegemonic International Law: rethinking human rights and development as a Third World strategy." ${ }^{14} \mathrm{He}$ argues that, notwithstanding the extent to which human rights has become bound up within a totalizing discourse of 'military intervention, economic reconstruction and social transformation', it is still 'legitimate to use international law as an explicit counter hegemonic tool of resistance'. ${ }^{15}$ In his view, some potential remains for human rights discourse to be mobilized by "counterhegemonic struggles across a range of areas from anti-war protests to market access for agricultural products of poor countries." ${ }^{16}$ Yet, the decisions about where and how these

\footnotetext{
${ }^{11}$ See, for example, International Law from Below, supra n. 3.

${ }^{12}$ Ibid, p. 292.

${ }^{13}$ Ibid, p. 293.

${ }^{14}$ Third World Quarterly, Vol. 27, no. 5, pp. 767-783 (2006).

${ }^{15}$ Ibid, pp. 770 and 772.

${ }^{16}$ Ibid, p. 772.
} 
connections may be made appear to lie outside the analysis, and indeed, even largely outside the law. Towards the end of a paper that has both insisted on the counterhegemonic potential of human rights in particular, and condemned human right groups for failing to 'stop the consolidation of hegemonic international law' and for their complicity in it, Rajagopal minimizes the significance of law to counter-hegemonic struggles. In summing up, he tells us that the prospects for the 'transformation of international law into a counter-hegemonic tool' are 'bleak on its own', and that the "future of the world-its ability to deal with problems of peace, war, survival, prosperity, planetary health and pluralism-depends on a range of factors, including the politics of the 'multitude', as Hardt and Negri call the governed'. ${ }^{17}$

The simultaneous invocation of both Partha Chatterjee's conception of the 'politics of the governed' and Hardt and Negri's notion of the 'multitude' as the conclusion to a paper that has persistently argued that international law, including human rights law, should be utilized as a site for counter-hegemonic politics, might be seen to undermine that claim. ${ }^{18}$ Chatterjee's conception stands on a critique of the modern form of the nation-state, and the limits of the related conceptions of civil society and political citizenship. For Chatterjee, the politics of the governed is located outside of these realms, in the heterogenous space of governmentality among the 'governed', whom he also calls 'political society' to distinguish them from the more limited and elitist spaces occupied by 'civil society'. ${ }^{19}$ This space is in tension with the homogenous timespace of modern law. The 'multitude' is also a conception of a political subject or political agency that stands in a different relation to the modern state and state law. That is, the multitude is conceived in relation to 'Empire' which itself is not a concept tied to any particular nation-state. It is more closely tied to contemporary forms of social regulation and governance that Hardt and Negri call 'biopower'. As Hardt and Negri sweepingly proclaim, "the multitude poses a clear challenge to the entire tradition of sovereignty". ${ }^{20}$ Their work demands that we engage with an arguably 'new' configuration-of sovereignty and governmentality coming together to produce a new biopolitical sovereignty. For some scholars, such as Judith Butler, this configuration is understood as standing in an inverse relation to law, ${ }^{21}$ but Hardt and Negri identify it, somewhat problematically, as a new form of law. ${ }^{22}$

\footnotetext{
${ }^{17}$ Ibid, p. 780.

${ }^{18}$ Ibid, p. 781. The balance of the somewhat lengthy conclusion is a pragmatic review of a variety of spaces within international law that could provide opportunities for counter hegemonic politics: they include regional international law, new alliances of third world states such as the G-21 that emerged to block the WTO negotiations in 2003 in Cancun and coalitions of states and social movements such as those that came together over cotton trade or access to medicines in the WTO. Although he deems them worthy of mention, the author doesn't seem to attribute much promise to any of the sites he identifies.

${ }^{19}$ Partha Chatterjee, The Politics of the Governed: Reflections on Popular Politics in Much of the World (Columbia U Press: 2004).

${ }^{20}$ Michael Hardt and Antonio Negri, Multitude: War and Democracy in the Age of Empire (Penguin Press: 2004) p. 100.

21 "I hope to show how procedures of governmentality, which are irreducible to law, are invoked to extend and fortify forms of sovereignty that are equally irreducible to law. Neither is necessarily grounded in law, and neither deploys legal tactics exclusively in their fields of respective operation.” Judith Butler, Precarious Life: The Powers of Mourning and Violence (London and N.Y. Verso: 2004) at p.55.

${ }^{22}$ Indeed, the entire project (of Empire) is identified at the outset as jurisprudential in nature, yet there is remarkably little attention paid to the workings of international legal institutions, which would figure for most international legal scholars, including third world legal scholars, as a very key part of the architecture of the current, unjust, international legal order. As these institutions authority and legitimacy is crucially premised upon states, an analysis which minimizes the continuing relevance of the nation-state to transnational governance, as Hardt and Negri's does, sheds little light on these parts of the international legal order. See Buchanan and Pahuja, "Legal Imperialism: Empire's Invisible Hand?” in The Empires New Clothes: Reading Hardt and Negri edited by Paul Passavant and Jodi Dean, Routledge, 2003.
} 
While only a brief, but arguably crucial, part of an analytically rich essay, Rajagopal's concluding section opens up a series of questions which it then leaves unresolved- what use can be made of the 'small, though important' role of law in the process of counter-hegemonic struggle? How do we know when international law is functioning in a hegemonic as opposed to counter-hegemonic manner? Might Hardt and Negri's biopolitical conception of the multitude aid us in traversing this difficult terrain?

\section{The 'Multitude' and Biopolitical Forms of Resistance}

We can find this turn towards a biopolitical approach to both law and resistance somewhat more explicitly developed in the concluding section of a recent article by Vasuki Nesiah, "“'Resistance in the Age of Empire: Occupied discourse pending investigation." ${ }^{23}$ Like Rajagopal, Nesiah sets out to examine several contemporary legal discourses that are seen (by the mainstream) as 'resistance vocabularies', and deftly reveals the ways that they function instead to hold in place an imperialist, or hegemonic legal order:

"This paper looks at key contemporary initiatives seeking to invoke international legal norms to undergird dissent in the international plane. While these initiatives aim to temper and protest at intervention and occupation, I conclude that they contribute instead to the production of legitimacy for empire. While they describe themselves as resistance vocabularies that are critically relevant to a moment described as 'a turning point in history', I argue that these initiatives perform a turning away from the historical."

Her analysis aims to historicize such episodes as the invocation of the laws of war in response to the revelations of torture at Abu Ghraib prison and the use of international legal norms of sovereignty and human rights to temper the policy of 'regime change' in order to reveal their profound inadequacies.

Nesiah recruits Hardt and Negri in support of her thesis that the arguments marshalled by international lawyers are 'far from being legitimate, relevant and meaningful' in an age where international law itself may be becoming obsolete in the face of what she (following Hardt and Negri) terms 'imperial justice'. ${ }^{24}$ In a powerful conclusion to a section of the article on the meaning of the ICJ Advisory Opinion on the "Legal Consequences of the Construction of a Wall in the Occupied Palestinian Territory' Nesiah sums up international law's inadequacies in the era of wars on terror:

"In this moment to capture the horrors of the wall in the denial of statehood is to swat a fly, to deter and defer a more challenging conversation about the aims of resistance. Today self-determination discourse is a terrain whose critical energies are spent-spent by a politics whose terms were limited by the nation-state; it has few resources to take on the more difficult internationalized politics of empire. The war on terror itself is a phenomenon of 'empire' and we need to develop vocabularies of resistance that engage with this historical habitus." 25

The majority of the article is devoted to the analysis of the shortcomings of current international legal discourses rather than an elaboration of new resistance vocabularies. Yet, some evocative directions are indicated in the last few pages. Nesiah argues that we 'need to have a better understanding of the evolving terrain for international law for a politics of

\footnotetext{
${ }^{23}$ Vasuki Nesiah, (2006) 23:5 Third World Quarterly 903-922.

${ }^{24}$ Ibid, p. 916.

${ }^{25}$ Ibid p.918.
} 
resistance." 26 She then goes on to suggest that we might map that terrain in terms of the Deleuzian conception of the commons and the networked or rhizomatic formations of biopolitical production that for Hardt and Negri constitute the 'multitude':

"The commons refers not to a commonality of interests or a coming together of different international actors; in that sense it is not referenced either by the private or the public, but, in fact, defined 'against' both. Partly reminiscent of Deleuze and Guattari's model of a network structure, the commons refers to the overlapping, intersecting competing networks that constitute 'our new global reality.'"27

For Hardt and Negri, the 'commons' is what emerges in the wake of the Westphalian order of sovereign state subjects. For the mainstream international lawyer, they suggest, it will simply appear as 'lack' but they conceive it as full --of biopolitical production. Again, we have 'law' and governmentality or 'biopolitics' as both mechanisms of governance and grounds for politics understood analytically as existing on separate tracks. And we are told that the latter is the track of the future, as it 'opens up possibilities for alternative social relationships, based on new legal relationships, multiple figures of normative production at local and global levels, and a variety of competing legal procedures. Once again, this is clearly not only a legal question, but also immediately economic, political, and cultural. ${ }^{28}$

One could and perhaps should say much more here about Hardt and Negri's strange/strained relationship to law, but they are not the primary concern of this essay. Rather, what is of interest is what in their analysis makes it attractive to the third world international legal scholar attempting to negotiate this difficult terrain of the relations between law and resistance. A final clue can be found in the 'optimistic thread' that Nesiah draws out of the final passage of Multitude. She observes that if a 'different political imagination is grounding our vocabularies of resistance, we also need a different conception of time and history." 29 That is, we need to be able to account for 'multiple historical trajectories situated in timelines that are split and fractured'. If our present moment is simultaneously post-9-11, post-1989, and post Bandung, how do we understand the possibilities for political action? In the end, this way of formulating the question comes closer, I would argue, to Chatterjee's 'heterogenous time of governmentality'30 than to Hardt and Negri. Hardt and Negri's conception of the split in time seems somehow more determined:

"We can already recognize that today time is split between a present that is already dead and a future that is already living - and the yawning abyss between them is becoming enormous. In time, an event will thrust us like an arrow into that living future." ${ }^{31}$

Nesiah's reading of this final passage is unclear, and notably, she pays no attention to the crux of it--the 'event', the revolution, that will suture the split in time and carry us into a different political future. Just as in Rajagopal, where the language of 'counter-hegemony' comes apparently without revolutionary baggage, it's not clear whether Nesiah is willing to ride Hardt and Negri's revolutionary arrow, nor whether she would share their conception of 'that living future'.

\footnotetext{
${ }^{26}$ Ibid p. 919.

${ }^{27}$ Ibid.

${ }^{28}$ Hardt and Negri, supra n. 20, p. 207 and quoted in Nesiah, ibid. p. 920.

${ }^{29}$ Nesiah, ibid.

${ }^{30}$ Chatterjee, supra n. 19, at p.8.

${ }^{31}$ Hardt and Negri, supra n. 20, at p. 358.
} 
It is interesting that for both Nesiah and Rajagopal, the recognition of the limits of international law's capacity to respond to the political demands they would make upon it leads to a precipitous turn to Hardt and Negri's biopolitical concepts of the multitude and the commons. I suspect that this might have to do with the way that Empire at least holds itself out as simultaneously engaging in both legal and political forms of analysis. While I would agree that a biopolitical approach is likely necessary for understanding the relations between international law and resistance in the current moment, Hardt and Negri are by no means the only, nor the most useful, avenue down which to turn. Indeed, there is a way in which their analysis begs the very questions for which these legal scholars turn to them for answers.

\section{Conclusion}

This essay has attempted, from a perspective that is sympathetic to the TWAIL enterprise, to think about what these ambiguities might reveal about the difficulties of writing critically about international law from a 'Third World' or subaltern perspective. There is an ambivalence here that arises out of the need to reconcile its engagement with the law within its commitment to radical social transformation. ${ }^{32}$ It is this very starting point that tends to lead one to the schizophrenic conclusion that law is both the whole problem and completely beside the point.

That is, the critical or third world international legal scholar finds herself suspended between two equally necessary answers to the question: 'what is the responsibility or the task of the jurist in revolutionary times, or perhaps in these revolutionary times'? ${ }^{33}$ On the one hand, Hans Morgenthau warned that "to struggle for absolute justice [is] to lose both relative justice and peace. Such an attitude may be proper for moralists or revolutionaries, but not for the jurist." ${ }^{\prime 34}$ On the other hand, Marxist international legal theorist China Mieville would argue that the jurist should abandon law and become a revolutionary, because the violence and power politics that the progressive jurist decries are inescapably the violence and power politics of juridical forms. Not that law allows or legitimates, let alone causes, such violence or politics, it is an expression of it. It is it. And, therefore the human necessity of revolution might mean the end of law." ${ }^{35}$

My suspicion is that there is something in the professional commitment of international lawyers, no matter how critical, that obscures the limits of their own (internal) critiques. While the deeply thoughtful and political arguments of scholars such as Nesiah and Rajagopal lead them right up to the edge of the abyss (the limits of law itself), they are unwilling or unable to envision the next step. Part of this suspension might be premised on an implicitly monist understanding of law that stands in the way of a meaningful engagement with the legal pluralism that many TWAIL scholars nonetheless recognize as necessary. Part of it may also have to do with the necessity of theorizing the 'event', that is, the need to address the usually unspoken question about the relationship between law, force and revolution. ${ }^{36}$ And finally, much of this productive tension might be seen to derive from the dueling commitments embraced by these third world international legal scholars whose work is illuminating precisely because it refuses the usual comfortable resting places.

\footnotetext{
32 See "Roundtable: War, Force and Revolution” chaired by Anne Orford, ASIL Proceedings 2006.

${ }^{33}$ Anne Orford, ibid.

${ }^{34}$ As quoted by Martti Koskenniemi, The Gentle Civiliser of Nations: The Rise and Fall of International Law 1870-1960 (2001) 458.

${ }^{35}$ China Mieville, ASIL Roundtable, supra n. 32.

${ }^{36}$ A notable exception would be the Roundtable on War, Force and Revolution” cited at supra note 32.
} 
